\title{
ANALYSIS OF PERCEPTION OF PATIENT CARE PATIENTS PHYSIOTHERAPY LOYALTY
}

\author{
Wijayantono ${ }^{1}$ Billy Harnaldo Putra ${ }^{2}$ dan Novan Asnandra ${ }^{3}$ \\ Magister Kesehatan Masyarakat STIKes Fort De Kock Bukittinggi \\ e-mail: opanradji@gmail.com
}

Submitted: 01-05-2018, Reviewer: 30-05-2018, Accepted: 10-03-2018

\begin{abstract}
Loyalty becomes a real form on the willingness patients for reuse, which has a strength and a positive attitude. Physiotherapy services is one form of health services needed by the community. The purpose of this study to analyze the patient's perception of physiotherapy outpatient unit of physiotherapy services to the loyalty of patients at Ibnu Sina Islamic Hospital Bukittinggi. The research method with a combination of research methods(mixedmethod), with the design of sequential explanatorydesign.Samples are old patient who came to Physiotherapy Unit, the sampling technique accidental sampling (quantitative) and purposive sampling (qualitative) as many as 110 patients a long time and the number of informants 3 patients. Data analysis usingtest, Chi Squareand qualitative analysis. Based on the results, unfavorable patient's perception regarding tangible (60.9\%), reliability (80\%), responsivenes (92.7\%), assurance (88.2\%), except empaty (82.7\%), with the lack of loyalty patients $(73.6 \%)$ in the physiotherapy unit. The absence of a relationship between the patient's perception ofphysiotherapy tangibleservices, reliability, responsivenes, assurance, and empathy, loyalty patient in the hospital. Islam Ibnu Sina Bukittinggi. Interviews, observation and document study research shows perceptions poorly to 4 variable tangible, reliability, responsivenes, assurance except empathy variable perception of good, judging from the many shortcomings in terms of infrastructure and the patient is less loyal and need factors are factors that influence loyalty patient in an outpatient physiotherapy unit. It is expected for the Hospital in order to further optimize both in terms of facilities and infrastructure, and increase the number of officers physiotherapy unit.
\end{abstract}

Keywords: Loyalty; Perception; Physiotherapy services

\begin{abstract}
ABSTRAK
Loyalitas menjadi suatu bentuk nyata atas kesediaan pasien untuk menggunakan kembali, yang memiliki kekuatan dan sikap positif. Pelayanan Fisioterapi merupakan salah satu bentuk pelayanan kesehatan yang dibutuhkan masyarakat. Tujuan penelitian ini menganalisis persepsi pasien unit fisioterapi rawat jalan tentang pelayanan fisioterapi terhadap loyalitas pasien di RS.Islam Ibnu Sina Bukittinggi.Metode penelitian dengan metode penelitian kombinasi (mixmethod), dengan desain sequential explanatory design. Sampel penelitian adalah pasien lama yang datang ke Unit Fisioterapi, dengan teknik pengambilan sampel accidental sampling (kuantitatif) dan purposive sampling (kualitatif) sebanyak 110 pasien lama dan jumlah informan 3 orang pasien. Analisis data menggunakan uji Chi Square,dan analisis kualitatif.Berdasarkan hasil penelitian didapatkan persepsi pasien kurang baik mengenai tangible $(60,9 \%)$, reliability $(80 \%)$, responsivenes $(92,7 \%)$, assurance $(88,2 \%)$, kecuali empaty $(82,7 \%)$, dengan kurangnya loyalitas pasien $(73,6 \%)$ di unit fisioterapi. Tidak adanya hubungan antara persepsi pasien pelayanan fisioterapi tentang tangibel, reliability, responsivenes, assurance, dan empathy, terhadap loyalitas pasien di RS. Islam Ibnu Sina Bukittinggi. Hasil wawancara, observasi, dan telaah dokumen penelitian menunjukkan persepsinya kurang baik terhadap 4 variabel tangible, reliability, responsivenes, assurance kecuali variabel empati persepsi baik, dilihat dari banyak kekurangan dari segi sarana dan prasarana serta pasien kurang loyal dan faktor kebutuhan merupakan faktor yang mempengaruhi loyalitas pasien di unit fisioterapi rawat jalan.Diharapkan bagi pihak Rumah Sakitagar dapat lebih mengoptimalkan lagi baik dari segi sarana maupun prasarana, dan menambah jumlah petugas unit fisioterapi.
\end{abstract}

Kata kunci: Loyalitas; Persepsi; Pelayanan Fisioterapi 


\section{PENDAHULUAN}

Pelayanan kesehatan menurut Depkes RI (2009) adalah setiap upaya yang diselenggarakan sendiri atau secara bersama-sama dalam organisasi untuk memlihara dan meningkatkan kesehatan, mencegah dan menyembuhkan penyakit serta memulihkan kesehatan perorangan, keluarga, kelompok dan ataupun masyaratakat.Salah satu bentuk sarana pelayanankesehatan yang dapat diselenggarakan olehpemerintah dan swasta adalah rumah sakit.Rumah Sakit terus berkembang baik dalamjumlah, kapasitas maupun sarana prasaranaseiring dengan perkembangan teknologi.Walaupun terdapat perkembangan RumahSakit dari waktu ke waktu, tetapi fungsidasar Rumah Sakit tetap tidak berubah.Fungsi dasar adalah pemulihan kesehatananggota masyarakat, baik denganpelayanan rawat inap, maupun rawat jalan,serta konsultasi pemeliharaan atauperawatan kesehatansesuai denganKepMenkesRI.No.340/MENKES/ PER/III/2010.

Tuntutan kualitas menjadi prioritas di Indonesia khususnya dalam pelayanan di rumah sakit. Kualitas pelayanan Rumah Sakit fokus pada 5 dimensi yaitu tangible (bukti langsung) , reliability (kehandalan), ,responsiveness (daya tanggap), assurance (jaminan), dan empathy atau empati (Kesuma, dkk. 2013).

Fisioterapi adalah bentuk pelayanan kesehatan yang ditujukan kepada individu dan/ kelompok untuk mengembangkan, memelihara dan memulihkan gerak dan fungsi tubuh sepanjang rentang kehidupan dengan menggunakan penanganan secara manual, peningkatan gerak, peralatan (physics, elektroterapeutis dan mekanis) pelatihan fungsi, dan komunikasi (Permenkes RI No.65,2015). Pelayanan Fisioterapi merupakan salah satu bentuk pelayanan kesehatan yang dibutuhkan masyarakat. Pelayanan fisioterapi rumah sakit merupakan salah satu kegiatan di rumah sakit yang menunjang pelayanan kesehatan yang bermutu.

Loyalitas menjadi suatu bentuk nyata atas kesediaan pasien untuk menggunakan kembali, yang memiliki kekuatan dan sikap positif (Fitriani, 2014). Loyalitas dari konsumen tentu tidak langsung muncul saat pertama kali tetapi baru akan muncul ketika mereka sudah berulang kali mengakses pelayanan kesehatan di sebuah rumah sakit.Loyalitas pasien yang terbentuk karena merasa puas dengan pelayanan di rumah sakit, bermanfaat bagi pengobatan karena pasien kembali berobat di tempat yang sama dan lebih patuh dalam proses kontrol kesehatan yang dianjurkan (Otani,et al.2010) dalam (Fahmi.2012).

Kondisi menurunnya jumlah kunjungan pasien lama menjadi permasalahan yang harus diperhatikan oleh manajerial rumah sakit, mungkin pengaruh/petunjuk dari loyalitas pasien yg menurun. Jumlah pasien yang menurun akan berpengaruh terhadap pemasukan/income rumah sakit khususnya unit fisioterapi. Persepsi pasien terhadap mutu pelayanan, mungkin juga dapat mempengaruhi loyalitas pelayanan pasien pada pasien lama. Berdasarkan rata-rata kunjungan pasien Fisioterapi di RSAM Bukittinggi dan di RS.Islam Ibnu Sina Bukittinggi dari bulan ke bulan, bahwa rata-rata kunjungan pasien fisioterapi ke RS.Islam Ibnu Sina Bukittinggi rendah.

\section{METODE PENELITIAN}

Metode penelitian dengan metode penelitian kombinasi(mixed method), dengan desain sequential explanatory design.Sampel dalam penelitian ini adalah semua pasien lama yang telah melakukan kunjungan di Unit Fisioterapi dan akan melakukan kunjungan selanjutnya hingga bulan Oktober 2017 dan 3 informan, Pemilihan Informant ditentukan dengan purposive sampling. 


\begin{abstract}
Pengambilan sampel dengan menggunakan teknik accidental sampling yaitu dengan mengambil setiap pasien lama yang datang ken Unit Fisioterapisesuai kriteria inklusi sampai tercapai jumlah yangditentukan, dengan jumlah sampel 110 responden.Kuisioner ini digunakan dalam penelitian dan sudah di ujicobakan kepada 15 orang pasien lama di Unit Fisioterapi Rawat Jalan RS Islam Ibnu Sina. Bukittinggi. Kuisioner yangdipergunakan sudah memenuhi syarat validitas dan reliabilitas dengan nilai signifikansi 5\%.Analisis bivariat menggunakan uji chi square,kemudian untuk mengetahui pengaruh variabel terhadap variabelterikat dengan analisis multivariat dengan uji regresi logistic. Analisis data kualitatif, Setelah
\end{abstract}

melakukan penelitian maka peneliti mengumpulkan dan mengklasifikasikan data sesuai pertanyaan yang ditentukan kemudian melakukan penyajian dalam bentuk narasi data kualitatif.

Setelah selesai dilakukan analisis kualitatif kemudian menafsirkan data, menemukan polahubungan dan serta membuat temuan- temuan dari hasil analisis data penelitian kuantititaf dan kualitatif serta membuat kesimpulan.

Validitas data kualitatif, validitas data dilakukan melalui upaya triangulasi yaitu dengan :Triangulasi Sumber data, Triangulasi Metodologi(Metodologi yang digunakan untuk penelitian ini adalah tiga metodologi yaitu dengan: (a) Wawancara mendalam, (b) Studi dokumentasi, (c) Observasi)

Tabel 1

Distribusi Frekuensi Responden tentang Tangibel, Reliability, Responsiveness, Assurance, Empathy, Loyalitasterhadap Penampilan Unit Fisioterapi RS.Islam Ibnu Sina Bukittinggi

\begin{tabular}{|c|c|c|c|}
\hline No & Persepsi Pasien tentang TangibelUnit Fisioterapi & $\mathbf{f}$ & $\%$ \\
\hline 1 & Baik $(\geq 31,32)$ & 43 & $39,1 \%$ \\
\hline \multirow[t]{2}{*}{2} & Kurang baik $(<31,32)$ & 67 & $60,9 \%$ \\
\hline & jumlah & 110 & 100 \\
\hline No & Persepsi Pasien tentang ReliabilityUnit Fisioterapi & $\mathbf{f}$ & $\%$ \\
\hline 1 & $\operatorname{Baik}(\geq 18,45)$ & 22 & $20 \%$ \\
\hline \multirow[t]{2}{*}{2} & Kurang baik $(<18,45)$ & 88 & $80 \%$ \\
\hline & jumlah & 110 & 100 \\
\hline No & $\begin{array}{llll}\text { Persepsi } & \text { Pasien } & \text { tentang } & \text { ResponsivenesUnit } \\
\text { Fisioterapi } & & & \end{array}$ & f & $\%$ \\
\hline 1 & $\operatorname{Baik}(\geq 9,15)$ & 8 & $7,3 \%$ \\
\hline \multirow[t]{2}{*}{2} & Kurang Baik $(<9,15)$ & 102 & $92,7 \%$ \\
\hline & jumlah & 110 & 100 \\
\hline No & Persepsi Pasien tentang AssuranceUnit Fisioterapi & $\mathbf{f}$ & $\%$ \\
\hline 1 & $\operatorname{Baik}(\geq 18,10)$ & 13 & $11,8 \%$ \\
\hline \multirow[t]{2}{*}{2} & Kurang Baik $(<18,10)$ & 97 & $88,2 \%$ \\
\hline & jumlah & 110 & 100 \\
\hline No & Persepsi Pasien tentang EmpathyUnit Fisioterapi & $\mathbf{f}$ & $\%$ \\
\hline 1 & $\operatorname{Baik}(\geq 11,95)$ & 91 & $82,7 \%$ \\
\hline \multirow[t]{2}{*}{2} & Kurang Baik $(<11,95)$ & 19 & $17,3 \%$ \\
\hline & jumlah & 110 & 100 \\
\hline No & Loyalitas Pasien tentang Pelayanan Unit Fisioterapi & $\mathbf{f}$ & $\%$ \\
\hline 1 & Loyal $(\geq 15,29)$ & 29 & $26,4 \%$ \\
\hline \multirow[t]{2}{*}{2} & Kurang loyal $(<15,29)$ & 81 & $73,6 \%$ \\
\hline & jumlah & 110 & 100 \\
\hline
\end{tabular}


HASILPENELITIAN

Deskripsi Analisis Univariat Variabel Penelitian (tabel 1.1)

1. Hasil Analisis Univariat Variabel Bebas Penelitian Kuantitatif

Distribusi frekuensi terhadap persepsi tangibelunit fisioterapi dijabarkan pada tabel 1.1 dimana dari tabel diatas diketahui responden yang mempunyai persepsi baik tentang tangibel terhadap penampilan unit fisioterapi lebih kecil $(39,1 \%)$ dibandingkan dengan persepsi kurang baik $(60,9 \%)$. Selain itu, diketahui responden yang mempunyai persepsi baik tentang reliability (kehandalan) pelayanan unit fisioterapi lebih kecil (20\%) dibandingkan dengan persepsi kurang baik $(80 \%)$.
Responden

mempunyaipersepsi responsivenes (daya tanggap) terhadap pelayanan unit fisioterapi lebih kecil $(7,3 \%)$ dibandingkan dengan persepsi kurang baik $(92,7 \%)$ dan responden yang mempunyai persepsi baik tentang assurance(jaminan) terhadap pelayanan unit fisioterapi lebih kecil (11,8\%) dibandingkan dengan persepsi kurang baik (88,2\%).Nilai persepsi pasien tentang empathy (empati) terhadap pelayanan unit fisioterapi RS.Islam Ibnu Sina Bukittinggiberkisardengan nilai ratarata 11,95(mean). Berdasarkan tabel diatas dapat diketahui bahwa responden yang loyal memiliki persentase yang lebih kecil $(26,4 \%)$ daripada responden yang kurang loyal $(73,6 \%)$.

Tabel 1.2

Tabel Silang antara Tangibel,Reliability, Responsivenes, Assurance, EmpathyUnit Fisioterapi dengan Loyalitas di RS.Islam Ibnu Sina Bukittinggi

\begin{tabular}{|c|c|c|c|c|c|c|c|}
\hline \multirow{3}{*}{$\begin{array}{l}\text { Persepsi Tangibel } \\
\text { Unit Fisioterapi }\end{array}$} & \multicolumn{4}{|c|}{ Loyalitas Pasien } & \multirow{2}{*}{\multicolumn{2}{|c|}{ Total }} & Pvalue \\
\hline & \multicolumn{2}{|c|}{ Loyal } & \multicolumn{2}{|c|}{ Kurang Loyal } & & & \multirow{5}{*}{0,337} \\
\hline & $\mathrm{N}$ & $\%$ & $\mathrm{~N}$ & $\%$ & $\mathrm{~N}$ & $\%$ & \\
\hline Baik & 14 & 32,6 & 29 & 67,4 & 43 & 100 & \\
\hline Kurang Baik & 15 & 22,4 & 52 & 77,6 & 67 & 100 & \\
\hline Total & 29 & 55 & 81 & 145 & 110 & 100 & \\
\hline \multirow{3}{*}{$\begin{array}{l}\text { Persepsi Reliability } \\
\text { Unit Fisioterapi }\end{array}$} & \multicolumn{4}{|c|}{ Loyalitas Pasien } & \multirow{2}{*}{\multicolumn{2}{|c|}{ Total }} & Pvalue \\
\hline & \multicolumn{2}{|c|}{ Loyal } & \multicolumn{2}{|c|}{ Kurang Loyal } & & & \multirow{5}{*}{0,871} \\
\hline & $\mathrm{N}$ & $\%$ & $\mathrm{~N}$ & $\%$ & $\mathrm{~N}$ & $\%$ & \\
\hline Baik & 5 & 22,7 & 17 & 77,3 & 22 & 100 & \\
\hline Kurang Baik & 24 & 27,3 & 64 & 72,7 & 88 & 100 & \\
\hline Total & 29 & 50 & 81 & 150 & 110 & 100 & \\
\hline \multirow{3}{*}{$\begin{array}{l}\text { Persepsi Responsiveness } \\
\text { Unit Fisioterapi }\end{array}$} & \multicolumn{4}{|c|}{ Loyalitas Pasien } & \multirow{2}{*}{\multicolumn{2}{|c|}{ Total }} & Pvalue \\
\hline & Loy & & Kur & Loyal & & & \\
\hline & $\mathrm{N}$ & $\%$ & $\mathrm{~N}$ & $\%$ & $\mathrm{~N}$ & $\%$ & \\
\hline Baik & 3 & 37,5 & 5 & 62,5 & 8 & 100 & 0,432 \\
\hline Kurang Baik & 26 & 25,5 & 76 & 74,5 & 102 & 100 & \\
\hline Total & 29 & 63 & 81 & 137 & 110 & 100 & \\
\hline \multirow{3}{*}{$\begin{array}{l}\text { Persepsi Assurance } \\
\text { Unit Fisioterapi }\end{array}$} & \multicolumn{4}{|c|}{ Loyalitas Pasien } & \multirow{2}{*}{\multicolumn{2}{|c|}{ Total }} & Pvalue \\
\hline & Loy & & Kur & Loyal & & & \\
\hline & $\mathrm{N}$ & $\%$ & $\mathrm{~N}$ & $\%$ & $\mathrm{~N}$ & $\%$ & \\
\hline Baik & 4 & 30,8 & 9 & 69,2 & 13 & 100 & 0,741 \\
\hline Kurang Baik & 25 & 25,8 & 72 & 74,2 & 97 & 100 & \\
\hline Total & 29 & 56,6 & 81 & 143,4 & 110 & 100 & \\
\hline \multirow{3}{*}{$\begin{array}{l}\text { Persepsi Empathy } \\
\text { Unit Fisioterapi }\end{array}$} & \multicolumn{4}{|c|}{ Loyalitas Pasien } & \multirow{2}{*}{\multicolumn{2}{|c|}{ Total }} & Pvalue \\
\hline & \multicolumn{2}{|c|}{ Loyal } & \multicolumn{2}{|c|}{ Kurang Loyal } & & & \multirow{5}{*}{1,000} \\
\hline & $\mathrm{N}$ & $\%$ & $\mathrm{~N}$ & $\%$ & $\mathrm{~N}$ & $\%$ & \\
\hline Baik & 24 & 26,4 & 67 & 73,6 & 91 & 100 & \\
\hline Kurang Baik & 5 & 26,3 & 14 & 73,7 & 19 & 100 & \\
\hline Total & 29 & 52,7 & 81 & 147,3 & 110 & 100 & \\
\hline
\end{tabular}




\section{Deskripsi Analisis Bivariat Variabel Penelitian}

Dari tabel 1.2 diatas dapat dijelaskan sebagai berikut Ada hubungan antara persepsi pasien tentang tangibel (bukti langsung) unit fisioterapi dengan loyalitas pasien dengan nilai $\mathrm{p}$ value sebesar 0,337 pada tingkat kesalahan $5 \%$ (pvalue > 0,05). Ada hubungan antara persepsi pasien tentang reliability (kehandalan) unit fisioterapi dengan loyalitas pasien dengan nilai $\mathrm{p}$ value sebesar $0,871 \mathrm{pada}$ tingkat kesalahan $5 \%$. (pvalue $>0,05$ ). Ada hubungan antara persepsi pasien tentang responsiveness(kehandalan) unit fisioterapi dengan loyalitas pasien dengan nilai $\mathrm{p}$ value sebesar 0,432 pada tingkat kesalahan $5 \%$. (pvalue $>0,05$ ). Ada hubungan antara persepsi pasien tentang assurance (jaminan)unit fisioterapi dengan loyalitas pasien. Setelah diolah nilai $\mathrm{p}$ value sebesar 0,741 (pvalue > $0,05)$. Ada hubungan antara persepsi pasien tentang empathyunit fisioterapi dengan loyalitas pasien. Setelah diolah nilai $p$ value sebesar 1,000 . (pvalue $>0,05$ ).

\section{PEMBAHASAN}

\section{Tangibel(bukti}

langsung)Unit

Fisioterapi RS.Islam Ibnu Sina

\section{Bukittinggi dengan Loyalitas Pasien}

Berdasarkan analisis hubungan antara variabel tangibel dengan loyalitas pasien dapat diketahui bahwa pada kelompok kurang loyal,proporsi responden yang menyatakan tangibel kurang baik sebesar $77,6 \%$, dengan nilai p-value sebesar 0,337(pvalue $>0,05$ ). Berarti Ho diterima sehingga tidak ada hubungan yang bermakna antara persepsi pasien tentang tangibel (bukti langsung) unit fisioterapi dengan loyalitas pasien.

Hal ini sesuai dengan penelitian Sari, 2013 dengan jumlah responden 100 bahwa variabel penampilan ( value $=0,259$ )tidak ada hubungan dengan loyalitas pasien.
Penelitian ini sejalan dengan penelitian yang dilakukan Kasih (2015) yang berjudul Analisis Hubungan antara Mutu Pelayanan dengan Loyalitas Pasien BPJS Non Penerima Bantuan Iuran di Rawat Inap Rumah Sakit Mardi Rahayu Kudus, yang menyatakan bahwa tidak ada hubungan antara dimensi tangible (bukti langsung) dengan loyalitas pasien. Dan penelitian Fattah (2016), dengan jumlah responden 83 tidak ada hubungan antara tangibel (Bukti Langsung) terhadap loyalitas pasien di RSIA Sitti Khadijah I Makassar dengan nilai $\mathrm{p}=0.060$ dimana nilai $\mathrm{p}>0,05$.

Penelitian ini tidak sejalan dengan penelitian yang dilakukan Sulni, dkk (2013) yang berjudul Hubungan Mutu Pelayanan Kesehatan dengan Loyalitas Pasien di Puskesmas Baranti Kabupaten Sidrap, yang menyatakan bahwa adanya hubungan yang bermakna antara tangibel (bukti langsung) dengan loyalitas pasien.

Hasil penelitian ini juga tidak sesuai dengan pendapat Zeithaml (2004) yang menyatakan bahwa tangible merupakan suatu hal yang secara nyata turut mmpengaruhi keputusan pasien untuk membeli dan menggunakan produk jasa yang ditawarkan. Dan menurut Gunawan \& Djati (2011) dimana penampilan rumah sakit umum swasta yang baik akan membuat pasien loyal.

Menurut Sari,2013, bahwa keinginan pasien untuk membeli kembali jasa pelayanan sangat dipengaruhi oleh sarana penunjang dan kenyamanan dalam menunggu. Dalam penelitian ini tangibelmeliputi lokasi unit fisioterapi, penampilan fisik unit terapi,kondisi ruang tunggu unit fisioterapi,toilet yang memadai,tersedia tv/koran/majalah/brosur untuk menghilangkan kejenuhan,dll.Menurut asumsi peneliti, pada penelitian ini tangibel tidak ada hubungan dengan loyalitas karena persepsi pasien yang kurang baik disebabkan penampilan fisik unit fisioterapi luas ruangannya sempit sehingga pasien kesulitan untuk akses 
didalam ruangan terapi dimana pasien antri juga didalam dan diluar ruangan terapi, unit terapi belum memiliki ruangan tindakan dan ruangan pemeriksaan secara terpisah, jumlah petugas yang kurang. Penampilan petugas juga harus diperhatikan terutama kerapian dan kebersihannya karena akan memberikan citra atau image tersendiri dimata konsumen tentang rumah sakit tersebut.

\section{Reliability (kehandalan)}

Berdasarkan analisis hubungan antara variabel reliability dengan loyalitas pasien dapat diketahui pada kelompok yang kurang loyal, proporsi responden yang menyatakan kurang baik yaitu $72,7 \%$, dengan nilai $\mathrm{p}$ value sebesar 0,871 . Berarti Ho diterima sehingga tidak ada hubungan yang bermakna antara persepsi pasien tentang reliability (kehandalan) unit fisioterapi dengan loyalitas pasien.

Hal ini sesuai dengan penelitian Sari, 2013 dengan jumlah responden 100 bahwa variabel kemudahan layanan (pvalue $=0,126$ ), kompetensi petugas (pvalue $=0,272$ ) tidak ada hubungan dengan loyalitas pasien.Hasil penelitian ini sejalan dengan penelitian yang dilakukan oleh Saragih, dkk (2010) yang berjudul Pengaruh Mutu Pelayanan Terhadap Loyalitas Pasien Rumah Sakit Umum Herna Medan.

Hal ini tidak sesuai dengan penelitian Jayadipraja, 2016 bahwa variabel reliability (pvalue $=0,000), \quad$ Dengan demikian, maka Ho ditolak dan $\mathrm{Ha}$ diterima berartiada hubungan dengan loyalitas pasien di RSUD Kendari. Dan penelitian Fattah, 2016, dengan jumlah responden 83, ada hubungan antara Reliability(kehandalan pelayanan)terhadap loyalitas pasien di RSIA Sitti Khadijah I Makassar dengan nilai $p=0.048$ atau nilai $p<0,05$.

Dalam penelitian ini reliability ditinjau dari aspek ketersediaan informasi, prosedur pelayanan, pasien terjadwal, tindakan petugas ke pasien cepat,akurat,tepat,petugas memberikan pelayanan tidak berbelit-belit,petugas dalam memberikan pelayanan terapi memuaskan.Menurut asumsi peneliti, tidak ada hubungan reliability dengan loyalitas karena persepsi pasien yang kurang baik dilihat dari informasi yang tersedia meliputi prosedur pelayanan pemeriksaan kurang memudahkan pasien dalam mendapatkan pelayanan fisioterapi.

Berdasarkan telaah dokumen, observasi dan wawancara mendalam pada penelitian ini informasi yang tersedia meliputi prosedur pelayanan pemeriksaan kurang memudahkan pasien dalam mendapatkan pelayanan fisioterapi.

\section{Responsiveness (daya tanggap)}

Berdasarkan analisis hubungan antara variabel responsiveness dengan loyalitas pasien dapat diketahui pada kelompok yang kurang loyal, proporsi responden yang menyatakan kurang tanggap $74,5 \%$. dengan nilai $\mathrm{p}$ value sebesar 0,432 . Berarti Ho diterima sehingga tidak ada hubungan yang bermakna antara persepsi pasien tentang responsiveness (kehandalan) unit fisioterapi dengan loyalitas pasien.Penelitian ini berbeda menurut Fattah,2016, dengan jumlah responden 83, ada hubungan antara responsiveness (daya tanggap) terhadap loyalitas pasien di RSIA Sitti Khadijah I Makassar dengan nilai $\mathrm{p}=0.036$ atau nilai $\mathrm{p}<0,05$.Penelitian yang dilakukan oleh Saragih, dkk (2010) yang berjudul Pengaruh Mutu Pelayanan Terhadap Loyalitas Pasien Rumah Sakit Umum Herna Medan, yang menyatakan terdapat hubungan yang signifikan antara responsiveness dengan loyalitas pasien.

Menurut asumsi peneliti tentang variabel responsiveness tidak berhubungan dengan loyalitas disebabkan karena kemampuan petugas untuk cepat tanggap menyelesaikan keluhan pasien dan tindakan petugas yang cepat saat pasien 
membutuhkan kurang tanggap. Ini dikarenakan jumlah petugas yang kurang cukup dengan jumlah pasien. Hal ini sesuai dengan standar pelayanan fisioterapi bahwa pemenuhan sumber daya manusia fisioterapis di fasilitas pelayanan kesehatan dalam hal ini di Rumah Sakit dilakukan berdasarkan analisis beban kerja dan/rasio pelayanan pasien/klien per hari kerja (1 fisioterapis : 8-10 pasien/klien per hari kerja) dengan mempertimbangkan kebutuhan kualifikasi fisioterapis yang sesuai (Permenkes RI No.65, 2015).Kecepatan pelayanan sangat penting karena pada masyarakat modern, waktu adalah komoditi yang tidak bisa diulang kembali..

\section{Assurance (jaminan)}

Berdasarkan analisis hubungan antara variabel assurance dengan loyalitas pasien dapat diketahui pada kelompok yang kurang loyal, proporsi responden yang menyatakan kurang jaminan $74,2 \%$.dengan nilai $p$ value sebesar 0,741.Berarti Ho diterima sehingga tidak ada hubungan yang bermakna antara persepsi pasien tentang assurance (jaminan)unit fisioterapi dengan loyalitas pasien.

Hal ini tidak sesuai dengan penelitian Jayadipraja, 2016 bahwa variabel assurance (pvalue $=0,000$ ) ada hubungan dengan loyalitas pasien di RSUD Kendari. Penelitian Fattah, 2016, dengan jumlah responden 83, diperoleh nilai ppada kategori assurance $($ jaminan pelayanan $)=$ 0.024 Dengan demikian, maka Ho ditolak dan Ha diterima berarti ada hubungan antara assurance (jaminan pelayanan) terhadap loyalitas pasien di RSIA Sitti Khadijah I Makassar.Penelitian ini tidak sejalan dengan penelitian yang dilakukan oleh Berlianty, dkk (2013) yang berjudul Analisis Loyalitas Pasien Berdasarkan Kualitas Pelayanan di Instalasi Rawat Inap RS Bhayangkara Mappa Oudang Kota Makassar.
Penelitian ini sejalan dengan penelitian yang dilakukan oleh Gunawan, dkk (2011) yang berjudul Kualitas Layanan dan Loyalitas Pasien Studi pada Rumah Sakit Umum Swasta di Kota Singaraja Bali, yang menyatakan bahwa assurance (jaminan pelayanan) tidak berpengaruh terhadap loyalitas pasien. Hasil penelitian Cronin et al.(2000) yang menyimpulkan dimensi assurance mempunyai hubungan dan pengaruh terhadap loyalitas.

Menurut asumsi peneliti, pada penelitian ini tidak ada hubungan antara assurance dengan loyalitas dilihat dari persepsi pasien yang kurang baik, yaitu sifat yang dapat dipercaya petugas dalam menjaga kerahasiaan informasi pasien masih diragukan oleh pasien,Disamping itu kemampuan petugas dalam menanamkan kepercayaan pasien terhadap pelayanan fisioterapi juga kurang.

Peningkatan jaminan dalam hal ini petugas sangat perlu untuk meningkatkan kepercayaan pasien terhadap proses fisioterapi yang dilakukan oleh petugas.Hal ini dapat ditingkatkan menurut Sari,2013 dengan melakukan pelatihan, pendidikan non formal, dan test kemampuan petugas dalam jangka waktu tertentu agar petugas memiliki skill yang diharapkan oleh pasien baik secara tekhnis maupun dari segi wawasannya.Jaminan adalah pengetahuan dan kesopanan karyawan serta kemampuan mereka untuk menimbulkan kepercayaan dan keyakinan (Kotler dan Amstrong. 2011).

\section{Empathy}

Berdasarkan analisis hubungan antara variabel empathy dengan loyalitas pasien dapat diketahui pada kelompok yang kurang loyal, proporsi responden yang menyatakan kurang empati $73,7 \%$.dengan nilai $p$ value sebesar 1,000.Berarti Ho diterima sehingga tidak ada hubungan yang bermakna antara 
persepsi pasien tentang Empathy unit fisioterapi dengan loyalitas pasien.

Hal ini tidak sesuai dengan penelitian Jayadipraja, 2016 bahwa variabel empati(pvalue $=0,000)$. Yang berarti ada hubungan empati dengan loyalitas pasien di RSUD Kendari.Dan penelitian Fattah, 2016, dengan jumlah responden 83, diperoleh nilaippada kategori Emphaty (Sikap Petugas $)=0.036$. Dengan demikian, maka Ho ditolak dan $\mathrm{Ha}$ diterima berarti ada hubungan antara Emphaty (Sikap Petugas) terhadap loyalitas pasien di RSIA Sitti Khadijah I Makassar.

Menurut asumsi peneliti pada penelitian ini tidak ada hubungan empati dengan loyalitas sedangkan persepsi pasien baik(empati) dikarenakan pasien yang datang lebih ke pasien rujukan untuk fisioterapi di RS.Islam Ibnu Sina Bukittinggi baik pasien BPJS maupun pasien umum.Hal ini berbeda dengan pendapat Sari, (2013)dalam pelayanan jasa, keramahan petugas dan kemudahan pelayanan merupakan faktor penting yang mempengaruhi persepsi pasien terhadap dimensi kualitas pelayanan.

Berdasarkan telaah dokumen, observasi dan wawancara mendalam pada penelitian ini tidak ada hubungan antara empati dengan loyalitas karena petugas dalam memberikan perhatian secara khusus kepada setiap pasien. kurang.Menurut asumsi peneliti juga, seorang pasien yang merasa diperhatikan oleh petugas akan menimbulkan rasa puas pada pasien tersebut, maka pelanggan/pasien akan berusaha untuk mengingat nama dan wajah petugas tersebut, dan tidak menutup kemungkinan setelah keluar dari rumah sakit pelanggan/pasien akan tetap menjalin hubungan yang baik dengan petugas tersebut.

\section{KESIMPULAN}

Berdasarkan hasil penelitian yang dilakukan terhadap 110 orang responden dan 3 informan tentang analisis persepsi pasien tentang pelayanan fisioterapi terhadap loyalitas pasien di unit fisioterapi rawat jalan RS.Islam Ibnu Sina bukittinggi, dapat ditarik kesimpulan yaitutidak adanya hubungan antara persepsi pasien pelayanan fisioterapi tentang tangibel, reliability, responsivenes, assurance, dan empathy, terhadap loyalitas pasien di RS. Islam Ibnu Sina Bukittinggi. Hasil wawancara, observasi, dan telaah dokumen penelitian menunjukkan persepsinya kurang baik terhadap 4 variabel tangible, reliability, responsivenes, assurance kecuali variabel empati persepsi baik, dilihat dari banyak kekurangan dari segi sarana dan prasarana serta pasien kurang loyal dan faktor kebutuhan merupakan faktor yang mempengaruhi loyalitas pasien di unit fisioterapi rawat jalan.Diharapkan bagi pihak Rumah Sakitagar dapat lebih mengoptimalkan lagi baik dari segi sarana maupun prasarana, dan menambah jumlah petugas unit fisioterapi.

\section{UCAPAN TERIMAKASIH}

Penulis mengucapkan terima kasih kepada RS.Islam Ibnu Sina Bukittinggi beserta Pimpinan dan staff khususnya petugas Unit Fisioterapi Rawat Jalan RS.Islam Ibnu Sina Bukittinggi yang telah memberikan kesempatan untuk melakukan penelitian dan membantu peneliti dalam melakukan penelitian.

\section{DAFTAR PUSTAKA}

Al-Damen Rula. 2017. Health Care Service Quality and Its Impact on Patient Satisfaction "Case of AlBashir Hospital" Canadian Center of Science and Education. Vol. 12, No. 9; 2017 ISSN 1833-3850 EISSN 1833-8119.

Anjaryani. 2009. Kepuasan Rawat Inap terhadap pelayanan perawat di RSUD Tegal rejo Semarang. (Tesis)Program Studi Magister Promosi Kesehatan.UNDIP Semarang. 
Ayubi Prastiwi. 2008. Hubungan Kepuasan Pasien Bayar Dengan Minat Kunjungan Ulang di Puskesmas Wisma Jaya Kota Bekasi Tahun 2007, http://repository.ui.ac.id/contents/k oleksi/2/a2c2b4b6259fa0140af803 6a711b6b78c46 8bb23.pdf, diakses tanggal 7 Agustus 2017.

Aliman dan Mohammad. 2015. Linking Service Quality, Patients Satisfaction and Behavioral Intentions: An investigation on Private Healthcare in Malaysia. Fakultas Bisnis Manajemen. Universitas Teknologi MARA. Perak. Malaysia.

Bustami. (2011). Penjamin Mutu Pelayanan Kesehatan dan Akseptabilitasnya. Padang: Erlangga.

Berlianty,dkk.(2013).Analisis Loyalitas Pasien Berdasarkan Kualitas Pelayanan Di Instalasi Rawat Inap RS.Bhayangkara Mappa Oudang Kota Makassar Tahun 2013. Bagian AKK Fakultas Kesehatan Masyarakat Universitas Hasanuddin.

Cronin,J.,k.,Michael G.Brady \& Thomas M.Hult.2000."Assesing The Effects of Quality,value, and Customer Satisfaction on Consumer Behavioral Intentions in Service Environtment",Journal of Retailing.

DepKes,RI,2008.Pedoman Pelayanan Fisioterapi Di Sarana Kesehatan.Dirjen Bina Pelayanan Medik.

DepKes,RI,2008.Pedoman

Penyelenggaraan Pelayanan Di Rumah Sakit

DKK, 2015. Profil Kesehatan Kota Bukittinggi.

Dewi,Ika,Sari.,2009.,Analisis Pengaruh Persepsi Pasien Tentang Bauran Pemasaran Terhadap Loyalitas Pasien Di Poliklinik Rawat Jalan RS Baptis Kediri, (Tesis),Program
Studi Magister Ilmu Kesehatan

Masyarakat

Konsentrasi

Administrasi

Rumah

Sakit,Universitas Diponegoro,

Semarang.

Fahmi,Andini,Sri,(2012).Faktor-Faktor Yang Berhubungan Dengan

Loyalitas Pasien Poliklinik Rawat Jalan Eksekutif RSUD Kota Bekasi Tahun 2012, (Skripsi),Fakultas Kesehatan Masyarakat Program Studi Kesehatan Masyarakat,Universitas Indonesia,2012.

Fitriani,Sri.2014.Pengaruh Kualitas Pelayanan Terhadap Loyalitas Melalui Kepuasan Pasien Pengguna BPJS Di Rawat Inap Dr.Moewardi. Program Studi Magister Manajemen, Program Pasca Sarjana Universitas Muhammadiyah Surakarta.

Fattah.Attika.2016.Hubungan Kualitas Pelayanan Kesehatan terhadap Loyalitas Pasien Di Rawat Inap Rumah Sakit Ibu Dan Anak Sitti Khadijah I Makassar Tahun 2016. (skripsi). Jurusan Kesehatan Masyarakat Fakultas Kedokteran Dan Ilmu Kesehatan Universitas Islam Negeri Alauddin Makassar 2016

Gunawan,Ketut dan

Djati,Pandja,Sundring.

(2011).Kualitas Layanan dan Loyalitas Pasien(Studi pada Rumah Sakit Umum Swasta di Kota Singaraja-Bali).Jurnal Manajemen dan

Kewirausahaan, Vol.

NO.1,Maret 2011:32-39.

Ginting,Serta,Ulina,2010. Perilaku Pasien Fisiotherapi Di Rumah Sakit (RS). Jurnal Ilmu Keolahragaan Vol. 8 (2) Juli Desember 2010.

Gazpersz, V., 2005. Total Quality Management. Jakarta: PT Gramedia Pustaka Utama. 
Griffin, Jill. (2005). Customer Loyalty: Menumbuhkan dan

Mempertahankan Kesetiaan

Pelanggan (Dwi Kartini Yahya, Penerjemah). Jakarta: Erlangga.

Hingarajia,Dharti.N. 2013. Psychometric Analysis of Patient Satisfaction with Physical Therapy Care. SPM Physiotherapy College. India.

Hardiyansyah. 2011.Kualitas Pelayanan Publik;Konsep,Dimensi,Indikator danImplementasinya."Yogyakarta.

Hanif, A.M. (2001). Analisis Tingkat Permintaan Paien terhadap Pelayanan Rawat Jalan di Poliklinik Penyakit Dalam RSUP dr. M. Djamil Padang.Depok. Tesis : FKM UI.

Jayadipraja,dkk.,2016.,Hubungan

Kualitas Pelayanan Terhadap Loyalitas Pasien Rawat Inap Umum Di Rumah Sakit Umum Daerah Kota Kendari Tahun 2016.Jurnal Fakultas Kesehatan Masyarakat Universitas Halu Oleo.,diakses tanggal 20 Februari 2017.

KepMenkes RI.2008.Standar Pelayanan Rumah Sakit. Kemenkes RI.

Kotler, P (2000). Marketing manajement, the millennium edition, tenth ed, New Jersey: prentice hall inc.

Kesuma, dkk. 2013. Service Quality Influence on Patient Loyality: Costumer Relationship Management as Mediation Variable. Fakultas Ekonomi dan Bisnis. Universitas Brawijaya.

Kusumapradja,Rokiah,dkk,2013.Analisis

Hubungan Antara Kualitas Pelayanan,Karakteristik

Pasien,dan Hambatan Pindah Dengan Loyalitas Pasien Rawat Jalan RSUD Cibinong,Fakultas Ilmu Kesehatan,Universitas Esa Unggul,Jakarta;Forum Ilmiah Volume 10 Nomor 1, Januari 2013.
Kelana,raden,chandra.2010.Analisis

Loyalitas Pasien \& Kualitas

Layanan di Poliklinik Ortodensi RSUP DR Hasan Sadikin

Bandung Tahun 2010;Fakultas

Kesehatan Masyarakat Universitas Indonesia.

Kasih, Bunga Mutiara Analisis Hubungan Antara Mutu Pelayanan Dengan Loyalitas Pasien Bpjs Non Penerima Bantuan Iuran (PBI) Rawat Inap Rumah Sakit Mardi Rahayu Kudus. Thesis, Diponegoro University, 2015

Marzban,et.al.,2015.,The Evaluation Of Outpatient Quality Services In Physiotherapy In The Teaching Health Centers Of Shhid Beheshti University Based On Servqual Tools., European journal of biology and Medical science research,Vol. 3,No.3,pp.4653,June.

Martha dan Kresno.2016.Metodologi Penelitian Kualitatif Dalam Bidang Kesehatan.PT.Raja Grafindo Persada,Jakarta.

Notoatmodjo, S. Ilmu Kesehatan Masyarakat. Prinsip- Prinsip Dasar. PT Rinneka Cipta. Jakarta. 2005.

Notoadmodjo, Soekidjo. (2007). Promosi Kesehatan dan Ilmu Perilaku. Jakarta: Rineka Cipta.

Nasim.Kanwal \& janjua saquib yusaf. (2014);service quality perceptions and patients satisfaction:a comparative case study of a public and a private sector hospital in pakistan;international journal for quality research 8(3) 447-460 issn 1800-6450.

Najar,et.al.2012.The Quality Assesment of Family Physician Service In Rural Regions, Northeast Of Iran.

Odebiyi, et al. 2009. Comparison of Patients' Satisfaction with Physiotherapy Care in Private and Public Hospital. Journal Of 
The Nigeria Society Of Physiotherapy - Vol. 17. Department of Physiotherapy, Lagos University Teaching Hospital, Idi Araba, Lagos.

Octaviani,Rolius 2014.Hubungan

Pengetahuan Ibu, Dukungan

Keluarga, Dan Peran Serta Kader

Terhadap Pemanfaatan Pos

Yandu Oleh Ibu Balita Di Jorong

Koto Tuo.(skripsi) Program Studi

Ilmu Kesehatan Masyarakat

Sekolah Tinggi Ilmu Kesehatan

Masyarakat,Stikes Fort De Kock

Bukittinggi.

Prasetyo,Bambang \&Jannah,Miftahul, (2010).Lina.Metode Penelitian Kuantitatif (Teori dan Aplikasi).Rajawali Pers.

Permenkes RI,2015., Standar Pelayanan Fisioterapi; Kemenkes RI.

Prabha Ramseook. 2010.Quality Of Service Measuring: Employee Perception.Global Journal Research Business.vol. 4, No. 1. Priatna,Heri.2017.Filsafat Ilmu

Fisioterapi. makalah Simposium Keilmuan Fisioterapi tanggal 3031 Maret.

Rahayu,Isti,Niken.,Mifbakhuddin.,2003;

Hubungan Antara Mutu

Pelayanan Fisioterapi Dengan

Kepuasan Pasien Pada Instalasi Rawat Jalan Poliklinik Fisioterapi RSUD Kabupaten Wonogiri; Jurnal Litbang Universitas Muhamadiyah Semarang.

Quintana M Jose. 2010. BMC Helath Services Research. Global Journal Research Business. Vol. 4, No 1.

Ramli. 2015. Building Patient Loyality in Healthcare Services.International Review of Management and Business Research. Vol. 4 Issue.2 www.irmbrjournal.com.

Santoso Imam. 2013. Manajemen Data.yogyakarta. Gosyen Publishing
Siti Setiati.Siti.2009, buku ajar Ilmu Penyakit Dalam .FKUI, jilid I.edisi V.

Sugiyono. Metode Penelitian. Suatu Pendekatan Praktik. Alfabeta, Bandung. 2004.

Sugiyono. Statistika Untuk Penelitian. Alfabeta, Bandung. 2006.

Sugiyono.2013. Metode Penelitian Bisnis (pendekatan kuantitatif,kualitatif dan $R \& D)$. Alfabeta: Bandung.

Sitayani,dkk., 2013.,Hubungan Kepuasan Dengan Loyalitas Pasien Rawat Inap Rumah Sakit Umum Daerah Kabupaten Pangkep.,Jurnal AKK Fakultas Kesehatan Masyarakat Universitas Hasanudin.

Sari,Amelia.,2013.,Analisis Pengaruh Persepsi Pasien Tentang Pelayanan Farmasi Terhadap Loyalitas Pasien Di Apotek Rawat Jalan Rumah Sakit Stroke Nasional Bukittinggi, (Tesis), Program Studi Magister Farmasi Fakultas Farmasi Universitas Andalas Padang.

Saragih, Rosita. Arlina Nurbaity Lubis. Raras Sutatniningsih. Pengaruh Mutu Pelayanan Kesehatan Terhadap Loyalitas Pasien Rumah Sakit Umum Herna Medan. Jurnal. Medan : Fakultas Kesehatan Masyarakat Universitas Sumatera Utara, 2010.

Supartiningsih Solichah. 2017. Kualitas Pelayanan dan Kepuasan Pasien Rumah Sakit. Jurnal Medicoeticolegal. Vol. 6, No. (1):9-15.

Sulni, Yuyun Arya. Darmawansyah. Indar. Hubungan Mutu Pelayanan Kesehatan dengan Loyalitas Pasien di Puskesmas Baranti Kabupaten Sidrap Tahun 2013. Jurnal. Makassar : Fakultas Kesehatan Masyarakat, Universitas Hasanuddin, 2013.

Sunaryo.,2015.,Psikologi Untuk Keperawatan., Edisi 2, Penerbit 
Buku Kedokteran, EGC., Jakarta, hal 18, 95.

Siyoto,Sandu.,Ariyanti,Mareta,Dewi.2016.An alisis Loyalitas Berdasarkan Tingkat Kepuasan Peserta Badan Penyelenggara Jaminan Sosial Non Penerima Bantuan Iuran Pada Pasien Rawat Jalan Di Puskesmas Ngletih Kota Kediri.STIKES Surya Mitra Husada Kediri

Tuhumena,Ruben.,dkk.,2011., Analisis Pengaruh Kualitas Layanan,Kepuasan,dan Loyalitas Terhadap Niat Berprilaku Pasien Rumah Sakit Umum Daerah (RSUD) Jayapura.,Jurnal Aplikasi Manajemen Volume 9 Nomor 3 Mei.

Tennakoon dan Zoysa. 2014. Patient satisfaction with physiotherapy services in an asian country: a report from sri lanka. Hong Kong Physiotheraphy Journal. Elsevier.

Tjiptono, Fandy, Gregorius Chandra. 2005. Manajemen Jasa. Edisi Ketiga. Yogyakarta : Andi Offset. Umah,Khoiroh.,Wati,Shofiyah.,2014., Hubungan Kepuasan Pasien Dengan Loyalitas Pasien; Journal of Ners Community Vol 5 No 2.
Vafaee Ali. 2012. The quality assessment of family physician service in rural regions, Northeast of Iran in 2012. Northeast of Iran. Vol. 2, No. 137-142.

Verhoef, P. C., Franses, P. H. and Hoekstra, J. C. (2002). The effect of relational constructs on customer referrals and number of services purchased from a multiservice provider: does age of relationship matter? Journal of the Academy of Marketing Science, 30(3), 202-216.

Windarko,Arif.,dkk.,2013., Analisis Pelayanan Fisioterapi Terhadap Kepuasan Pasien Rawat Jalan Reguler Di Unit Rehabilitasi Medik Di RSUD DR Moewardi, (skripsi),Program Studi Kesehatan Masyarakat Fakultas Kesehatan Universitas Muhamadiyah Surakarta,2013.

Wibowo, A. 2014. Metodologi Penelitian Praktis Bidang Kesehatan.Rajawali Pers.Jakarta.

Zarei Asghar, et.al. 2012.RESEARCH ARTICLE Open Access Service Quality Of Private Hospitals: The Iranian Patientsl Perspective. BMC Health Services Research. 